\title{
Cellular Physiology

\section{Platelet-Activating Factor Receptor Mediates Oxidized Low Density Lipoprotein-Induced Migration of Bone Marrow-Derived Mesenchymal Stem Cells}

\author{
Sang Hun Shin ${ }^{1,2}$, Hae Young Song ${ }^{1,2}$, Min Young Kim ${ }^{1,2}$, Eun Kyung \\ $\mathrm{Do}^{1,2}$, Koan Hoi Kim ${ }^{3}$ and Jae Ho Kim ${ }^{1,2}$

\begin{abstract}
${ }^{1}$ Medical Research Center for Ischemic Tissue Regeneration, Medical Research Institute, ${ }^{2}$ Department of Physiology, ${ }^{3}$ Department of Pharmacology, School of Medicine, Pusan National University, Gyeongsangnam-do
\end{abstract}

\section{Key Words}

Platelet-activating factor - Oxidized low density lipoprotein - Mesenchymal stem cells - Migration • Chemotaxis

\begin{abstract}
Background: Oxidized low density lipoprotein (oxLDL) is involved in the development of vascular diseases. Platelet-activating factor (PAF; 1-O-alkyl-2-acetyl-snglyero-3-phosphorylcholine) is a key component of oxLDL. Methods: In the present study, we evaluate whether oxLDL can regulate migration of human bone-marrow derived stem cells (hBMSCs) and characterize the role of PAF in the oxLDL-induced migration. Results and Conclusions: oxLDL stimulated chemotaxis of hBMSCs in vitro. Treatment of the cells with BN52021, a specific antagonist of PAF receptor (PAF-R), completely blocked the cell migration induced by PAF, but not platelet-derived growth factor (PDGF-BB). Using PAF-R-specific small interfering RNA, it was demonstrated that silencing of endogenous PAF-R expression significantly attenuated cell migration induced by PAF, but not PDGF-BB, suggesting the specific involvement of PAF-R in the oxLDL-induced cell migration. In addition, PAF-induced migration of hBMSCs was
\end{abstract}

\section{KARGER}

Fax +4161306 1234

E-Mail karger@karger.ch

www.karger.com
(C) 2010 S. Karger AG, Basel

$1015-8987 / 10 / 0265-0689 \$ 26.00 / 0$

Accessible online at:

www.karger.com/cpb abrogated by pretreating cells with mitogen-activated protein kinase (MAPK) inhibitors, including the MEK inhibitor U0126, the p38 MAPK inhibitor SB202190, and the JNK inhibitor SP600125. Moreover, adenoviral overexpression of a dominant negative mutant of p38 MAPK blocked PAF-stimulated migration. Taken together, these results suggest that PAF plays a pivotal role in the oxLDL-induced recruitment of hBMSCs through mechanisms involving PAF-Rdependent activation of MAPKs.

Copyright (C) 2010 S. Karger AG, Basel

\section{Introduction}

Atherosclerosis is a chronic inflammatory disease [1]. Intimal retention and oxidative modification of low density lipoprotein (LDL) play a pivotal role in the development of atherosclerosis [2]. Oxidized LDL (oxLDL) is incorporated into macrophages, leading to transformation of macrophages to foam cells and atherosclerotic plaque formation [3]. In addition, oxLDL reportedly induces oxidative injury in endothelial cells, smooth muscle cells, and macrophages, resulting atherosclerotic progression [4]. OxLDL has been

Jae Ho Kim, Ph.D.

Department of Physiology, School of Medicine, Pusan National University

Yangsan 626-870, Gyeongsangnam-do (Republic of Korea)

Tel. +82-51-510-8073, Fax +82-51-510-8076

E-Mail jhkimst@pusan.ac.kr 
suggested to be involved in various atherogenic steps in the vascular wall such as endothelial dysfunction, migration of smooth muscle cells, and secretion of inflammatory cytokines $[1,2]$. However, the molecular mechanism associated with oxLDL-induced cell migration remains elusive.

Oxidation of LDL leads to the formation of numerous oxidized lipid species including plateletactivating factor (PAF; 1-O-alkyl-2-acetyl-sn-glycero-3phosphocholine) from phospholipids [5]. OxLDL reportedly contains PAF-like phospholipid activating vascular cells or immune cells [6, 7]. Under normal physiological conditions, PAF is minimally produced; however, it is abundantly produced under inflammatory conditions associated with atherosclerosis and tissue injury [8]. PAF is associated with cardiovascular pathophysiology, including atherosclerosis, cardiac dysfunction, and myocardial ischemia-reperfusion injury [9]. PAF reportedly stimulates migration of various cell types, including smooth muscle cells, endothelial cells, and cancer cells [10-12]. The PAF effects are mediated through a $G$ protein-coupled PAF receptor (PAF-R) [13]. Consistent with the diverse cellular responses associated with PAF, activation of the PAF-R stimulates numerous signal transduction pathways including phospholipase C, D, A 2 and mitogen-activated protein kinases (MAPKs) such as extracellular signal-regulated kinase (ERK) and p38 MAPK [8, 13].

Mesenchymal stem cells (MSCs) possess selfrenewal capacity, long-term viability, and differentiation potential toward diverse cell types, such as adipogenic, osteogenic, chondrogenic, and myogenic lineages [14]. MSCs can be isolated from a variety of tissues, including bone marrow, adipose tissue, peripheral blood, articular cartilage and synovial tissue [14-16]. MSCs have the potential to differentiate to smooth muscle cells [17-19], suggesting a potential role as progenitor cells for vascular smooth muscle cells. Recent evidence indicates that MSCs are also present in normal artery wall and microvessels [20, 21]. An increasing body of evidence supports the potential involvement of MSCs in the development of atherogenesis and vascular remodeling [22]. However, it is still unclear whether oxLDL can regulate the migration of MSCs.

The present study was undertaken to examine the effects of oxLDL on cell migration of human bone marrow-derived mesenchymal stem cells (hBMSCs). The results demonstrate that PAF mediates the oxLDLinduced migration of hBMSCs through signaling pathways involving MAPKs.

\section{Materials and Methods}

Materials

$\alpha$-Minimum essential medium ( $\alpha$-MEM), trypsin, fetal bovine serum (FBS), and Lipofectamine ${ }^{\mathrm{TM}} 2000$ reagent were purchased from Invitrogen (Carlsbad, CA). U0126, SP600125, and SB202190 were from BIOMOL (Plymouth Meeting, PA). Anti-ERK, anti-phospho-ERK, anti-c-Jun N-terminal kinase (JNK), anti-phospho-JNK, anti-p38 and anti-phospho-p38 antibodies were from Cell Signaling Technology (Beverly, MA). Peroxidase-labeled secondary antibodies and the enhanced chemiluminescence (ECL) kit were purchased from Amersham Biosciences (Franklin Lakes, NJ). Human platelet-derived growth factor-BB (PDGF-BB) was purchased from R\&D Systems (Minneapolis, MN). PAF and LDL were purchased from Sigma-Aldrich (St. Louis, MO).

\section{Cell culture}

After informed consent, heparinized bone marrow cells were obtained from different individuals undergoing total hip arthroplasty and hBMSCs were isolated as previously described [23]. Briefly, mononuclear cells from bone marrow were separated by centrifugation in a Ficoll-Hypaque gradient $\left(\right.$ density $=1.077 \mathrm{~g} / \mathrm{cm}^{3}$; Sigma-Aldrich), and seeded at a concentration of $1 \times 10^{6}$ cells $/ \mathrm{cm}^{2}$. Cultures were maintained at $37^{\circ} \mathrm{C}$ in a humidified atmosphere containing $5 \% \mathrm{CO}_{2}$ in a growth medium comprised of $\alpha$-MEM, $10 \%$ fetal bovine serum, 100 units $/ \mathrm{ml}$ of penicillin, and $100 \mu \mathrm{g} / \mathrm{ml}$ of streptomycin until cell growth reached confluence. The primary hBMSCs were subcultured in tissue culture dishes at a concentration of 2,000 cells $/ \mathrm{cm}^{2}$. The hBMSCs were c-kit, CD34, and CD45 negative and greater than $90 \%$ CD29, CD44, CD90, and CD105 positive were used in the experiments.

\section{Lipoprotein preparation}

Native LDL (Sigma) was oxidized by exposure to $5 \mu \mathrm{M}$ $\mathrm{CuSO}_{4}$ in PBS at $37^{\circ} \mathrm{C}$ for 24 hours [24]. The concentration of LDL protein was determined using Bradford protein assay reagent (Bio-Rad). All LDL or oxLDL concentrations used in the experiments were normalized to this protein concentration. For oxidation, LDL was dialyzed against sterile PBS and $10 \mu \mathrm{M}$ diethylenetriamine pentaacetic acid (DTPA) and incubated with oxidant $25 \mu \mathrm{M} \mathrm{CuSO}_{4}$ for $14-16 \mathrm{~h}$ at $37^{\circ} \mathrm{C}$. The oxidation reaction was stopped by the addition of $100 \mu \mathrm{M}$ DTPA. Oxidative modification was verified as enhanced mobility by use of agarose gel electrophoresis.

\section{Cell migration assay}

Migration of hBMSCs was assayed using a Boyden chamber apparatus, as previously described [25]. Briefly, hBMSCs were harvested with $0.05 \%$ trypsin containing $0.02 \%$ EDTA, and suspended in $\alpha$-MEM at a concentration of $2 \times 10^{5}$ cells $/ \mathrm{ml}$. Membrane filters $(8-\mu \mathrm{m}$ pore size) in disposable $96-$ well chemotaxis chambers (Neuro Probe, Gaithersburg, MD) were pre-coated overnight with $20 \mu \mathrm{g} / \mathrm{ml}$ rat-tail collagen at room temperature. Aliquots $(50 \mu 1$ per well) of the cell suspension were loaded into the upper chambers, and test reagents were placed in the lower chamber, unless otherwise specified. To

Shin/Song/Kim/Do/Kim/Kim 


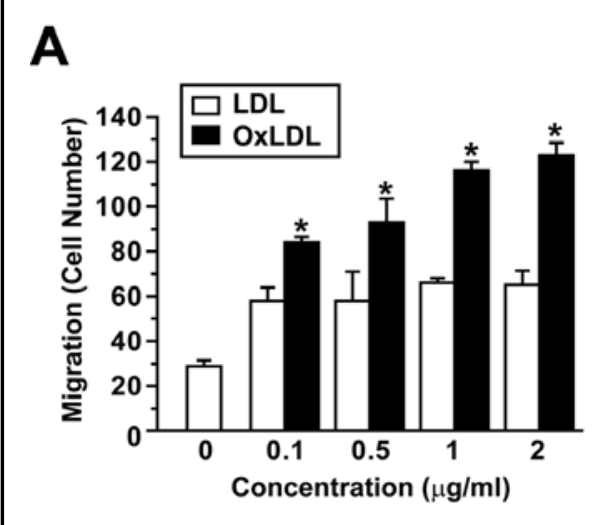

B

Fig. 1. Effects of oxLDL and LDL in migration of hBMSCs. (A) hBMSCs were loaded into the upper chambers of the Boyden apparatus and serum-free medium containing the indicated concentrations of oxLDL or LDL were placed in the lower chambers. The numbers of migratory hBMSCs were determined after $12 \mathrm{~h}$ as described under "Materials and Methods". Data represent mean \pm S.D. $(\mathrm{n}=4) .{ }^{*}, p<0.01 v s$ LDL. (B) Checkerboard analyses of the oxLDL-induced migration. oxLDL $(2 \mathrm{ig} / \mathrm{ml})$ or vehicles was placed in either the bottom, top, or both chambers of the Boyden apparatus, and cells were allowed to migrate for $12 \mathrm{~h}$. Data represent mean \pm S.D. $(\mathrm{n}=4)$. * indicates $p<0.01$.

elucidate the signaling pathways involved in PAF-induced migration, cells were pre-incubated with pharmacological inhibitors for $15 \mathrm{~min}$ before loading. After incubation of the cells with PAF in the absence or presence of the inhibitors for $12 \mathrm{~h}$ at $37^{\circ} \mathrm{C}$, the filters were disassembled, and the upper surface of each filter was scraped free of cells by wiping it with a cotton swab. The numbers of cells that had migrated to the lower surfaces of each filter were determined by microscopically counting the cells in four places (x100 magnification) after staining with hematoxylin and eosin. To elucidate whether the PAF-induced cell migration represented chemotaxis (directed migration) or chemokinesis (random migration), checkerboard analysis was performed as follows. hBMSCs were resuspended in $\alpha$-MEM in the absence or presence of PAF just before they were transferred to the upper chamber, and serum-free $\alpha$-MEM containing PAF or vehicles was added in the lower chamber for generation of concentration gradients of PAF between the upper and the lower compartments. The number of migrated cells on the lower surface of filters was determined by microscopic counting.

\section{Western blotting}

hBMSCs were incubated with serum-free $\alpha$-MEM for 24 $\mathrm{h}$, and the cells were treated with appropriate conditions, washed with ice-cold phosphate buffered saline (PBS), and then lysed in lysis buffer (20 mM Tris-HCl, 1 mM EGTA, $1 \mathrm{mM}$ EDTA, $10 \mathrm{mM} \mathrm{NaCl}, 0.1 \mathrm{mM}$ phenylmethylsulfonyl fluoride, 1 $\mathrm{mM} \mathrm{Na} \mathrm{VO}_{4}, 30 \mathrm{mM}$ sodium pyrophosphate, $25 \mathrm{mM} \beta$-glycerol phosphate, $1 \%$ Triton $\mathrm{X}-100, \mathrm{pH} 7.4)$. The proteins in the lysates were resolved by $10 \%$ sodium dodecyl sulfate-polyacrylamide gel electrophoresis (SDS-PAGE), transferred to a nitrocellulose membrane, and stained with $0.1 \%$ Ponceau S solution (SigmaAldrich) to ensure equal loading. After blocking with 5\% nonfat

PAF-Induced Migration of Mesenchymal Stem Cells milk, the membranes were immunoblotted with primary antibodies, and the bound antibodies were visualized with horseradish peroxidase-conjugated secondary antibodies using the ECL Western blotting system (ECL, Amersham Biosciences).

\section{Reverse transcription-polymerase chain reaction ( $R T$ - PCR)}

Cells were treated as indicated, and total cellular RNA was extracted by the Trizol method (Invitrogen). For RT-PCR analysis, aliquots of $2 \mu \mathrm{g}$ RNA were subjected to cDNA synthesis with $200 \mathrm{U}$ of M-MLV reverse transcriptase (Invitrogen) and $0.5 \mu \mathrm{g}$ of oligo(dT) 15 primer (Promega, Madison, WI). The cDNA in $2 \mu \mathrm{l}$ of the reaction mixture was amplified with $0.5 \mathrm{U}$ of GoTaq DNA polymerase (Promega) and 10 pmol each of sense and antisense primers as follows: PAFR, sense 5'-TAC TGC TCT GTG GCC TTC CT-3', anti-sense 5'CTG CCC TTC TCG TAA TGC TC-3'; glyceraldehyde-3phosphate dehydrogenase (GAPDH), sense 5'-TCC ATG ACA ACT TTG GTA TCG-3', antisense 5'-TGT AGC CAAATT CGT TGT CA-3'. The thermal cycle profile was as follows: denaturation at $95{ }^{\circ} \mathrm{C}$ for $30 \mathrm{~s}$, annealing at $53-55^{\circ} \mathrm{C}$ for $45 \mathrm{~s}$ depending on the primers used, and extension at $72{ }^{\circ} \mathrm{C}$ for $45 \mathrm{~s}$. Each PCR reaction was carried out for 30 cycles, and PCR products were size-fractionated on $1.2 \%$ ethidium bromide/ agarose gel and quantified under ultraviolet transillumination.

\section{Transfection with small interfering $R N A$}

Small interfering RNA (siRNA) duplexes for PAF-R (LQ005709-00) and non-specific control siRNA (D-001206-13-05) were purchased from Thermo Fisher Scientific. (Dharmacon, IL). For siRNA experiments, hBMSCs were seeded on 60-mmdiameter dishes. When growth reached $70 \%$ confluence, cells 


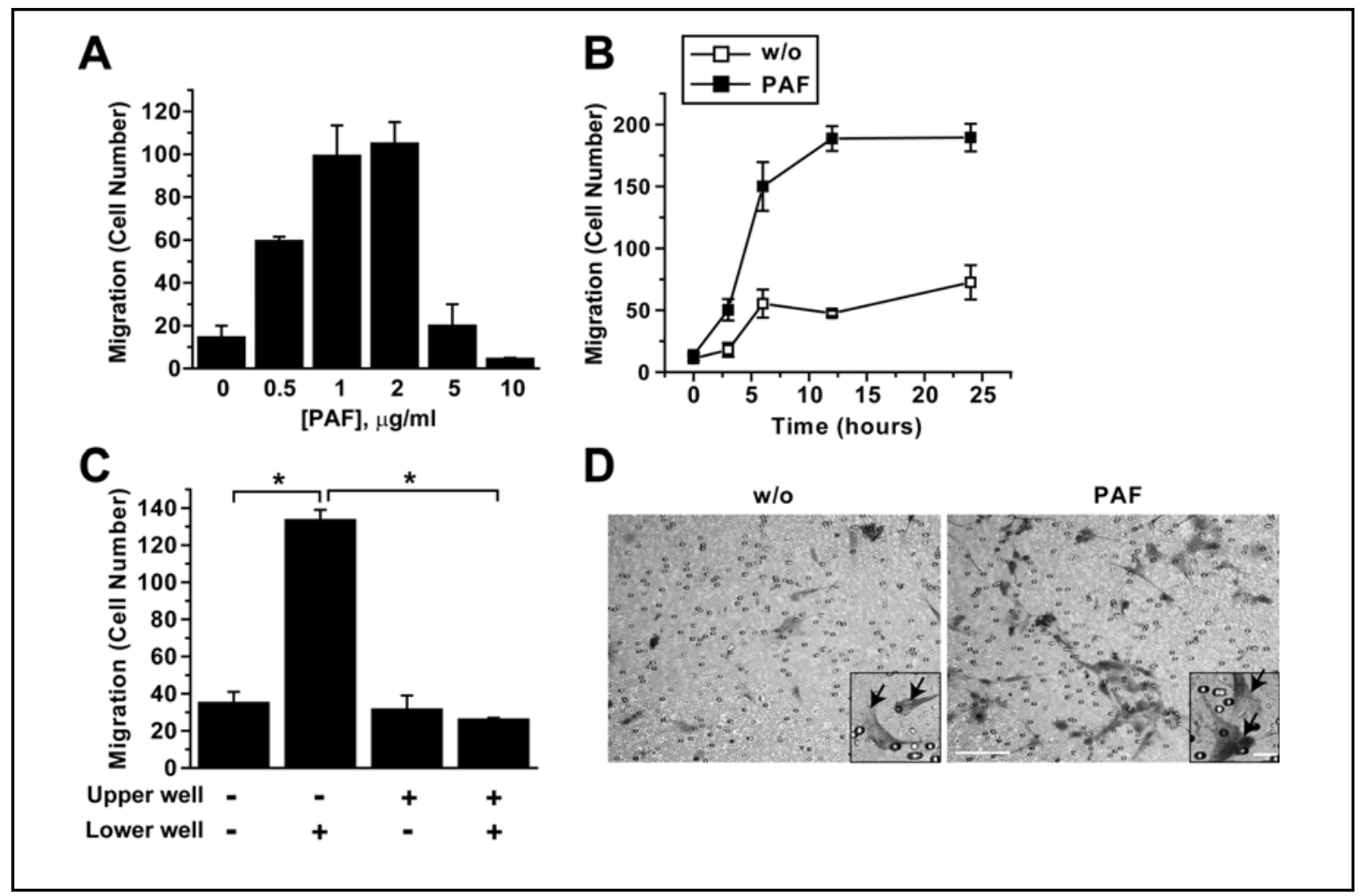

Fig. 2. Effects of PAF in the migration of hBMSCs. (A) hBMSCs were loaded into the upper chambers of the Boyden apparatus and serum-free medium containing the indicated concentrations of PAF were placed in the lower chambers. The numbers of migratory hBMSCs were determined after $12 \mathrm{~h}$ as described under "Materials and Methods". (B) Serum-free media containing $2 \mu \mathrm{g} / \mathrm{ml} \mathrm{PAF} \mathrm{or} \mathrm{vehicles} \mathrm{(w/o)} \mathrm{were} \mathrm{added} \mathrm{into} \mathrm{the} \mathrm{lower}$ chambers and the number of hBMSCs migrated to the lower surface of filters was determined after the indicated time periods. (C) Checkerboard analyses of the PAF-induced migration. $2 \mu \mathrm{g} / \mathrm{ml}$ PAF or vehicles was placed in either the bottom, top, or both chambers of the Boyden apparatus as noted, and cells were then allowed to migrate for $12 \mathrm{~h}$. Data represent mean \pm S.D. $(n=4) .{ }^{*}$ indicates $\mathrm{p}<0.01$. (D) hBMSCs attached to the lower surfaces of each filter were photographed by a digital camera mounted on a microscopy (x200 magnification) after staining with hematoxylin and eosin (scale bar $=100 \mathrm{~nm}$ ). Magnified images are shown as inlets (x500 magnification; scale bar $=50 \mathrm{~nm}$ ) and migrated hBMSCs are indicated by arrows.

were transfected with siRNAs using Lipofectamine Plus ${ }^{\mathrm{TM}}$ reagent (Invitrogen) according to manufacturer's instructions. Briefly, reagent was incubated with serum-free medium for 15 min, and respective siRNAs were then added to the mixtures. After incubation for $15 \mathrm{~min}$ at room temperature, the mixtures were diluted with serum free medium and added to each well. The final concentration of siRNAs in each well was $100 \mathrm{nM}$. After incubation of hBMSCs in serum-free medium containing siRNAs for $4 \mathrm{~h}$, the cells were cultured in growth medium for 24 $h$, and the expression levels of PAF-R and GAPDH were determined by RT-PCR analysis.

\section{Adenoviral expression of a dominant negative p 38 MAPK mutant}

The gene encoding dominant-negative mutant of $\mathrm{p} 38$ MAPK (TY $>$ AF) [26] was kindly provided by Dr. J. Han (The Scripps Research Institute, La Jolla, CA) and used for production of recombinant adenoviruses using the AdEasy system (Stratagene, La Jolla, CA). Recombinant adenoviruses were amplified and purified by density gradient ultracentrifugation according to the manufacturer's manual. For adenoviral infection, exponentially growing hBMSCs were infected with the appropriate amount of adenoviruses and incubated at $37{ }^{\circ} \mathrm{C}$ for $2 \mathrm{~h}$ with gentle shaking. Afterwards, fresh growth medium was added to each dish and further incubated for $48 \mathrm{~h}$. The expression levels of the dominant negative mutant of p38 MAPK (DN-p38 MAPK) was determined by Western blot analysis.

\section{Statistical analysis}

The results of multiple observations are presented as means \pm SD. Statistical significance was assessed using ANOVA and Scheffe's post hoc test, where indicated in the figure legends. 


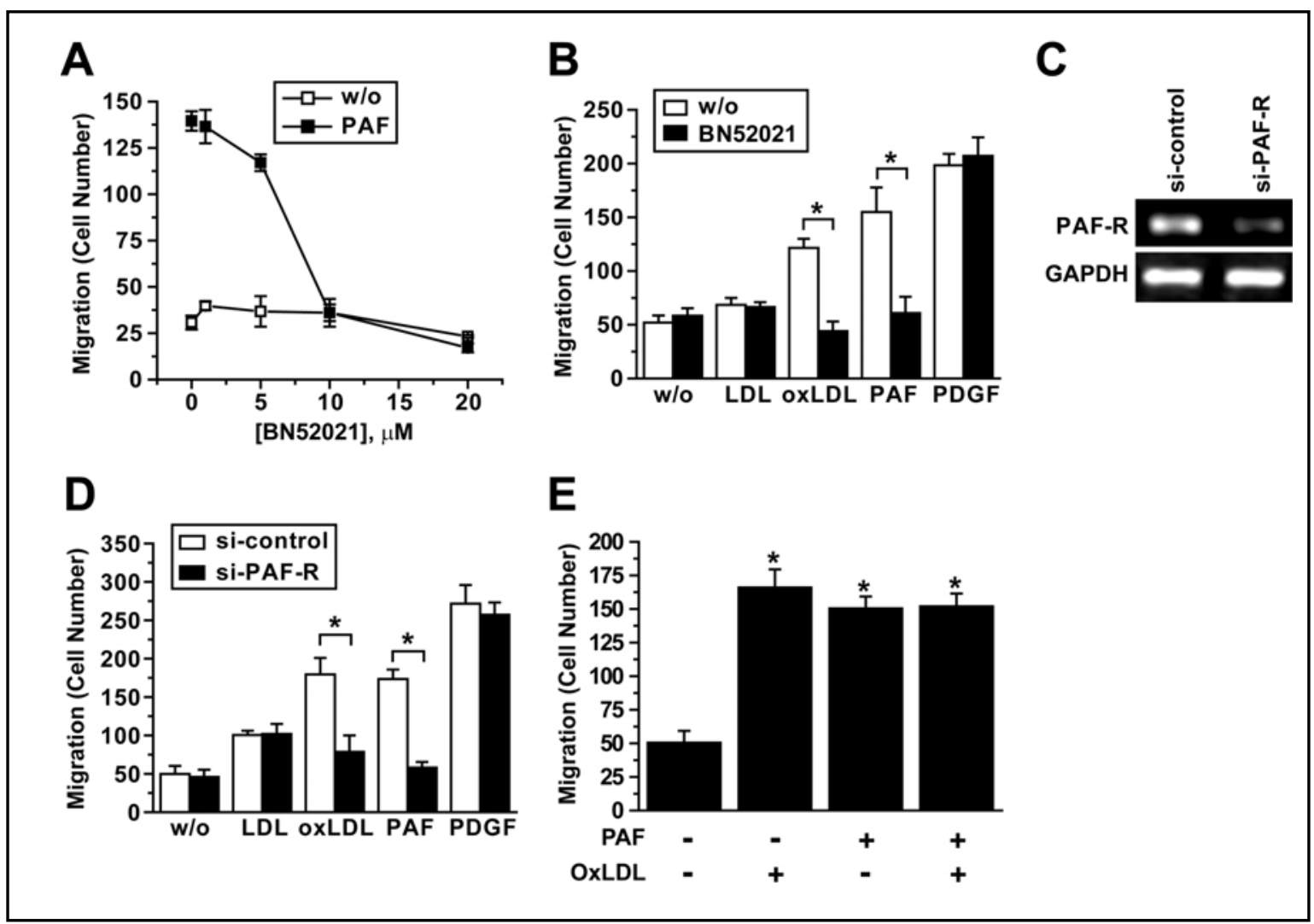

Fig. 3. Role of PAF receptor in the oxLDL-induced chemotaxis of hBMSCs. (A) hBMSCs were pretreated with indicated concentrations of BN52021 for $15 \mathrm{~min}$, loaded into the upper chamber, and serum-free medium containing vehicles (w/o) or $2 \mu \mathrm{g} / \mathrm{ml}$ were added to the lower chambers. (B) hBMSCs were pretreated with 10 $\mu \mathrm{M}$ BN52021 or vehicles (w/o) for $15 \mathrm{~min}$ before loading into the upper chamber and serum-free medium containing $2 \mu \mathrm{g} / \mathrm{ml}$ PAF, $2 \mu \mathrm{g} / \mathrm{ml}$ oxLDL, $2 \mu \mathrm{g} / \mathrm{ml} \mathrm{LDL}$, or $10 \mathrm{ng} / \mathrm{ml}$ PDGF-BB were added to the lower chamber. (C) hBMSCs were transfected with either control siRNA (si-control) or PAF-R-specific siRNAs (si-PAF-R) and the mRNA levels of PAF-R and GAPDH were determined by RT-PCR. (D) The siRNA-transfected hBMSCs were exposed to serum-free media containing $2 \mu \mathrm{g} / \mathrm{ml}$ PAF, $2 \mu \mathrm{g} / \mathrm{ml}$ oxLDL, $2 \mu \mathrm{g} / \mathrm{ml} \mathrm{LDL}$, or $10 \mathrm{ng} / \mathrm{ml}$ PDGF-BB. (E) hBMSCs were treated with a combination of $2 \mu \mathrm{g} / \mathrm{ml}$ PAF and $2 \mu \mathrm{g} / \mathrm{ml}$ oxLDL. The number of migrated cells to lower surface of the filters was determined after $12 \mathrm{~h}$. Data represent mean \pm S.D. $(n=4) .{ }^{*}, \mathrm{p}<0.01$ by two-way ANOVA and Scheffe's post hoc test.

\section{Results}

\section{OxLDL- induced migration of hBMSCs}

To explore whether oxLDL can regulate migrating ability of hBMSCs, the effects of oxLDL and LDL on cell migration were determined using Boyden chamber apparatus. As shown in Fig. 1A, oxLDL dose-dependently stimulated migration of hBMSCs and the stimulatory effect of oxLDL was more potent than that of LDL. To evaluate whether the oxLDL-induced cell migration was due to chemotaxis (directed migration) or chemokinesis (random migration), "checkerboard" analysis was performed. OxLDL-induced migration occurred in the presence of a positive concentration gradient between two compartments (higher concentration below the filter). In the presence of equal concentrations of oxLDL above and below the filter or of a negative gradient (higher concentration above the filter), no migration occurred (Fig. $1 B)$, suggesting chemotactic migration of hBMSCs in response to oxLDL.

\section{PAF stimulates migration of hBMSCs}

In order to test whether PAF could regulate migrating ability of hBMSCs, the effect of PAF on the migration of hBMSCs was determined. PAF dose-dependently stimulated migration of $\mathrm{hBMSCs}$ with a maximal induction at $1 \mu \mathrm{g} / \mathrm{ml}$ (Fig. 2A). Moreover, PAF time-dependently increased migration of $\mathrm{hBMSCs}$ and the PAF-induced 
Fig. 4. Role of MAPKs in the PAF-induced migration of hBMSCs. (A) hBMSCs preincubated in the absence or presence of 10 $\mu \mathrm{M} \mathrm{U} 0126,10 \mu \mathrm{M}$ SP600125, or $10 \mu \mathrm{M}$ SB202190 for 15 min were stimulated with 2 $\mu \mathrm{g} / \mathrm{ml}$ of PAF for $10 \mathrm{~min}$. The phosphorylation and expression levels of ERK, JNK, and p38 MAPK were analyzed by Western blotting. Representative data from three independent experiments are shown. (B-C) hBMSCs were pretreated with vehicles, 10 $\mu \mathrm{M}$ U0126, $10 \mu \mathrm{M}$ SP600125, or $10 \mu \mathrm{M}$ SB202190 for $15 \mathrm{~min}$, and then exposed to serum-free medium containing $2 \mu \mathrm{g} / \mathrm{ml}$ PAF (B) or $2 \mu \mathrm{g} / \mathrm{ml}$ oxLDL (C) in the absence or presence of the pharmacological inhibitors for $12 \mathrm{~h}$. The number of migrated cells was counted and data represent means \pm S.D. $(\mathrm{n}=4)$. * indicates $\mathrm{p}<0.01$ by two-way ANOVA and Scheffe's post hoc test.

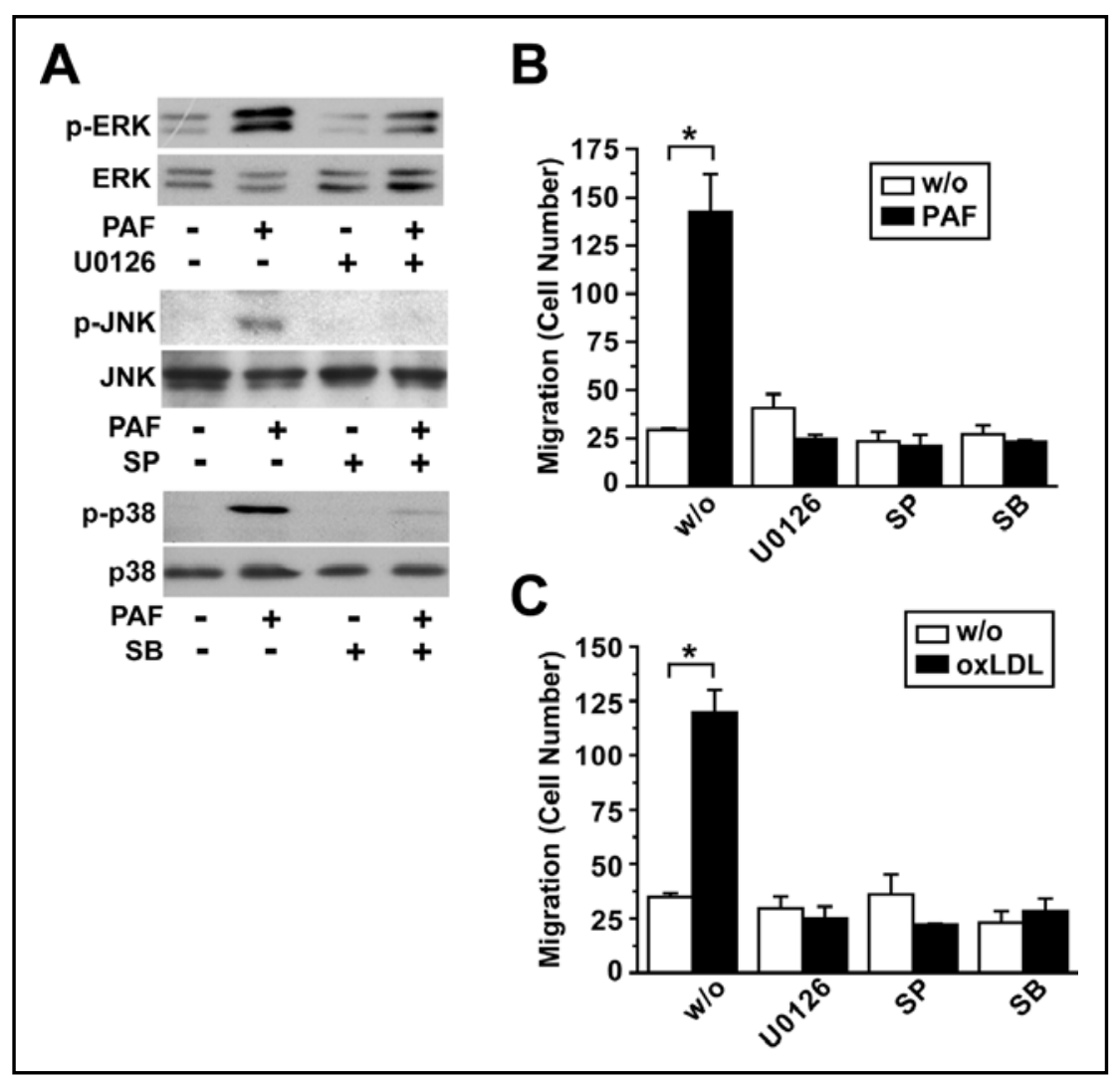

migration was maximum after exposure of $\mathrm{hBMSC}$ for $12 \mathrm{~h}$ (Fig. 2B). The PAF-induced cell migration was mediated by chemotaxis, because cell migration occurred in the presence of PAF in the lower chamber (Fig. 2C), indicating that PAF induces a chemotactic response in hBMSCs with no appreciable chemokinetic activity. hBMSCs normally exhibited fibroblast-like morphology and the morphology of hBMSCs was not apparently changed after PAF-induced chemotactic migration (Fig. 2D).

$P A F-R$ is involved in oxLDL-induced migration of $h B M S C s$

OxLDL contains PAF and PAF-like phospholipids [27], and PAF-R is responsible for the diverse biological responses of PAF [13]. To explore whether the oxLDLinduced cell migration is mediated by PAF-R, the effects of the PAF-R-specific antagonist BN52021 on PAFstimulated migration of hBMSCs were examined. As shown in Fig. 3A, BN52021 dose-dependently inhibited the PAF-induced migration of hBMSCs. BN52021 $(10 \mu \mathrm{M})$ completely abrogated the cell migration induced by PAF and oxLDL (Fig. 3B). To ensure that BN52021 specifically inhibited PAF-induced migration, we determined the effects of BN52021 on the PDGF- induced migration of hBMSCs. As shown in Fig. 3B, BN52021 had no significant impact on the PDGF-BBinduced cell migration, suggesting a specific involvement of PAF-R in the migration of hBMSCs induced by oxLDL and PAF.

To confirm the notion that PAF-R is responsible for the oxLDL-induced cell migration, the effects of siRNA-mediated depletion of endogenous PAF-R on cell migration were assessed. As shown in Fig. 3C, mRNA levels of PAF-R in hBMSCs were diminished by transfection with PAF-R-specific siRNAs. PAF-induced migration of hBMSCs was completely abrogated by silencing of endogenous PAF-R expression (Fig. 3D). Furthermore, knockdown of PAF-R blocked the oxLDL-induced cell migration. However, PDGF-BBinduced cell migration was not affected by silencing of PAF-R. Consistent with these results, combined treatment of hBMSCs with saturating concentrations of oxLDL and PAF had no synergy or additive effects on cell migration when compared with either oxLDL or PAF was treated separately, indicating that oxLDL and PAF likely share downstream signaling mechanism (Fig. 3E). Taken together, these observations obviously suggest that PAF-R plays a pivotal role in the oxLDL-induced migration of hBMSCs. 
Fig. 5. Role of p38 MAPK in the PAFinduced cell migration. (A) hBMSCs were infected with adenoviruses bearing DN-p38 MAPK or LacZ at a multiplicity of infection (MOI) of 50 plaque forming units (pfu) for 48 $\mathrm{h}$. The expression levels of p38 MAPK were determined by Western blotting. Representative data from three independent experiments are shown. (B-C) The adenoviral infected and uninfected control cells were then exposed to serum-free medium containing $2 \mu \mathrm{g} / \mathrm{ml}$ PAF (B) or $2 \mu \mathrm{g} / \mathrm{ml}$ oxLDL (C) for $12 \mathrm{~h}$. The number of migrated cells was counted and data represent means \pm S.D. $(\mathrm{n}=4)$. * indicates $\mathrm{p}<0.01$ by two-way ANOVA and Scheffe's post hoc test.

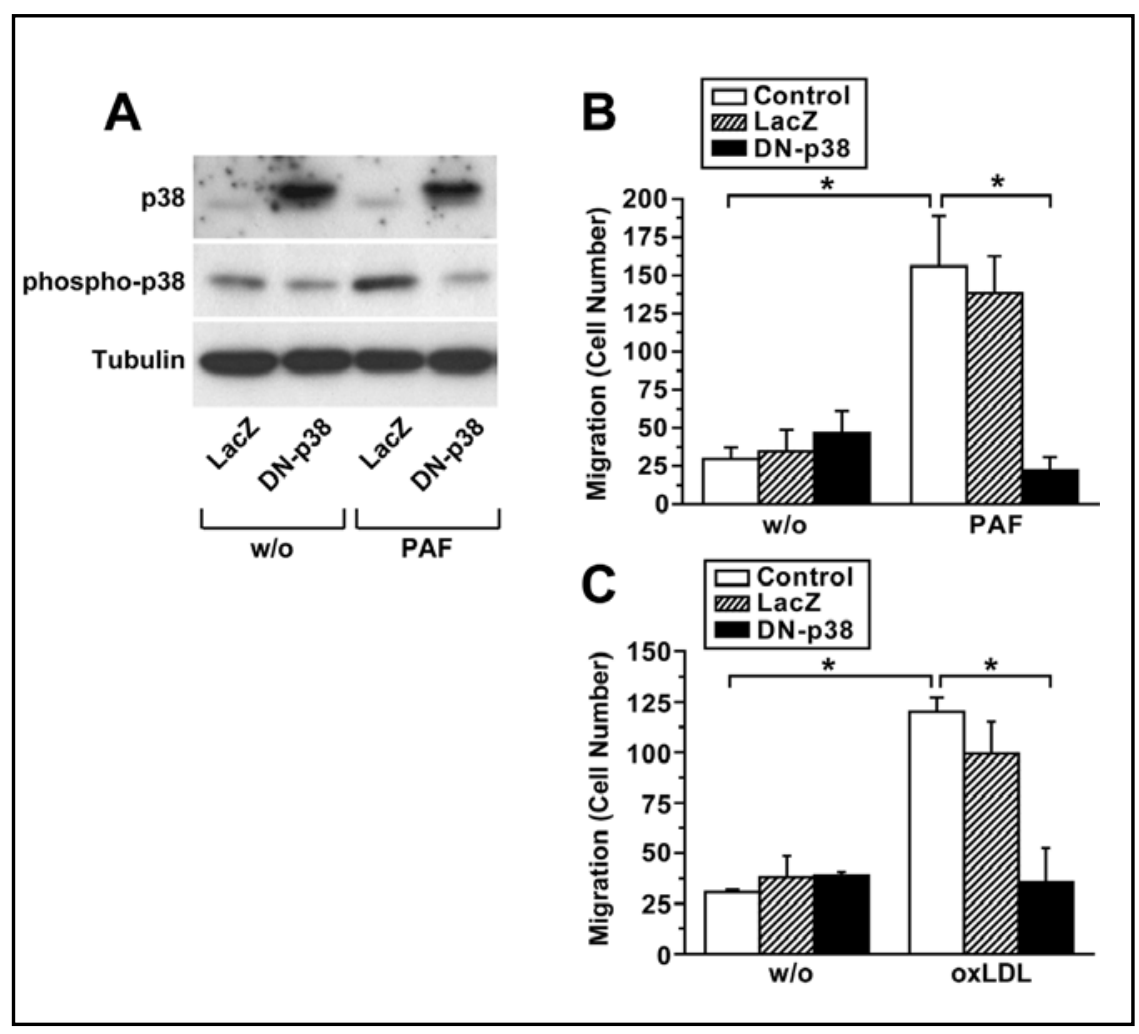

PAF induces migration of hBMSCs through $M A P K$-dependent mechanisms

PAF stimulates MAPKs including ERK and p38 MAPK [8, 13]. Appropriately, an experiment was conducted to determine the phosphorylation levels of three MAPKs, including ERK, JNK, and p38 MAPK, in response to PAF treatment. As shown in Fig. 4A, PAF increased phosphorylation levels of ERK, JNK, and p38 MAPK in hBMSCs. These phosphorylations were abrogated by pretreatment of the cells with U0126, SP600125, and SB202190, respectively. To elucidate the involvement of MAPKs in the PAF-induced migration, the effects of these pharmacological inhibitors on the PAFinduced migration of hBMSCs were determined. As shown in Fig. 4B, the PAF-stimulated migration of hBMSCs was abolished by pretreatment of the cells with U0126, SP600125, or SB202190. Furthermore, oxLDLinduced migration was also abrogated by pretreatment of the cells with U0126, SP600125, or SB202190. These results suggest that ERK, JNK, and p38 MAPK are involved in the migration of hBMSCs induced by PAF and oxLDL.

p38 MAPK plays a key role in PAF-induced migration of hBMSCs

Both ERK and JNK are reportedly implicated in migration of a variety of cell types. However, the role of p38 MAPK in cell migration is still elusive, in spite of prominent involvement of p38 MAPK in PAF-induced cell signaling $[8,13]$. To further support the role of p38 MAPK in PAF-induced migration, the effects of a dominant negative mutant of p38 MAPK (DN-p38 MAPK) on cell migration were examined. DN-p38 MAPK was overexpressed in hBMSCS using adenoviral expression system (Fig. 5A). Overexpression of DN-p38 MAPK blocked the PAF-induced phosphorylation of p38 MAPK. In addition, adenoviral over-expression of DN-p38 MAPK abrogated the migration of hBMSCs induced by either PAF or oxLDL (Fig. 5B and 5C). These results suggest that $\mathrm{p} 38$ MAPK is involved in the chemotaxis of hBMSCs induced by PAF and oxLDL.

\section{Discussion}

In the present study, we demonstrated that oxLDL potently stimulated migration of hBMSCs through a PAF/ PAF-R-dependent mechanism. Migration of hBMSCs induced by PAF and oxLDL was completely abrogated by pre-treatment with the PAF-R-specific antagonist BN52021 or siRNA-mediated depletion of endogenous PAF-R expression. PAF-induced activation of PAF-R stimulates migration of various cell types including 
endothelial cells, cancer cells, and a synthetic phenotype of smooth muscle cells [10-12]. OxLDL contains PAF and PAF-like phospholipids [27]. Activation of PAF-R is associated with oxLDL-induced chemokine release and adhesion in monocytes [7, 28]. Furthermore, oxLDL stimulates proliferation of smooth muscle cells through a PAF-R-dependent mechanism [6]. However, oxLDL particles are very heterogeneous in size, composition, and proportion of oxidized components. Therefore, it is difficult to determine the respective part of each constituent in their biological properties. Accumulating evidence suggests that the atherogenic properties of oxLDL are largely attributed to PAF and oxidized phospholipids, such as POVPC, and PGPC $[7,29]$. It has been reported that POVPC can activate PAF-R [30], suggesting that not only PAF but also oxidized phospholipids may be responsible for the oxLDL-induced cell migration. We found that POVPC can stimulate migration of hBMSCs through PAF-R-dependent mechanism (data not shown). Taken together, these results support a critical role of PAF-R in oxLDL-induced chemotactic migration of hBMSCs, although molecular identities of the factors associated with oxLDL-induced cell migration should be determined further.

PAF activates ERK in Chinese hamster ovary cells and human neutrophils $[13,31]$. Moreover, PAF induces activation of $\mathrm{p} 38 \mathrm{MAPK}$, ERK, and JNK in airway smooth muscle cells and primary hippocampal neurons $[32,33]$. However, the functional involvement of these MAPKs in the PAF-induced cell migration has not been clearly elucidated. Presently, PAF-induced migration of hBMSCs was abrogated by pretreatment with pharmacological inhibitors against ERK, JNK, or p38 MAPK, suggesting involvement of the three MAPK signaling pathways in PAF-induced cell migration. ERK, JNK, and p38 MAPK have been implicated in the regulation of cell migration of diverse cell types [34]. Overexpression of a constitutively active MEK1 mutant promoted the migration of FG carcinoma cells, whereas depletion of endogenous ERK by antisense oligonucleotides inhibited cell migration [35]. Furthermore, p38 MAPK is involved in migration of smooth muscle cells induced by PDGF, transforming growth factor- $\beta$, and interleukin- $1 \beta$ [36], and PDGF-induced migration of endothelial cells is dependent on p38 MAPK activation [37]. Consistently, the present data showed that adenoviral over-expression of DN-p38 MAPK abrogated the PAF-stimulated migration of hBMSCs. Taken together, these results support the notion that three MAPKs play a central part in the PAFinduced migration of hBMSCs.

MSCs reportedly migrate from bone marrow into injured tissues and tumor tissues, and, thus, play a role in tissue regeneration, fibrosis, and tumorigenesis [14, 38]. It has been documented that MSCs migrate in response to various protein factors, including PDGF, stromalderived factor-1, and monocyte chemoattractant protein1 [39-41]. In addition, accumulating evidence suggests that lipid-derived factors such as lysophosphatidic acid and sphingosine-1-phosphate are involved in migration of MSCs [42-44]. The findings of the present study implicate oxLDL-associated PAF as a chemotactic factor for MSCs. It has been shown that human umbilical vein endothelial cells exposed to oxLDL secreted SDF- $1 \alpha$ and paracrine activation of SDF-1 $\alpha-C X C R 4$ signaling axis stimulated migration and adhesion of BMSCs [45]. These results suggest that oxLDL can induce migration of BMSCs through direct activation of PAF-R or indirect activation of SDF- $1 \alpha-C X C R 4$ signaling axis. Because oxLDL plays a key role in the development of atherogenesis, it is conceivable that migrated MSCs play a key role in the development of atherogenesis in response to oxLDL or PAF. In line with this hypothesis, OxLDL has been reported to induce transdifferentiation of BMSC-derived smooth muscle-like cells to foam cells, which play a pivotal role in the development of atherosclerosis [46]. In addition, oxLDL inhibited osteogenic differentiation of BMSCs, whereas adipogenic differentiation of BMSCs was stimulated by oxLDL [47]. These results suggest that oxLDL may induce not only atherosclerosis but also osteoporosis by directing BMSCs to undergo adipogenic instead of osteogenic differentiation. In addition to the role of oxLDL-associated PAF in atherogenesis, PAF is mainly produced in response to inflammatory stimuli during tissue injury [8]. Therefore, it is tempting to speculate that PAF may be involved in the homing of MSCs into injured tissues, although it should be determined further whether PAF is involved in the migration of MSCs in vivo.

\section{Acknowledgements}

This work was supported by the MRC program of MOST/KOSEF (2010-0001251) and the Korea Research Foundation grants (KRF-2007-521-C00225). 


\section{References}

1 Ross R: Atherosclerosis-an inflammatory disease. N Engl J Med 1999;340:115-126.

$\checkmark 2$ Steinberg D: Atherogenesis in perspective: hypercholesterolemia and inflammation as partners in crime. Nat Med 2002;8:1211-1217.

-3 Steinberg D, Parthasarathy S, Carew TE, Khoo JC, Witztum JL: Beyond cholesterol. Modifications of low-density lipoprotein that increase its atherogenicity. N Engl J Med 1989;320:915-924.

$\checkmark 4$ Galle J, Hansen-Hagge T, Wanner C, Seibold S: Impact of oxidized low density lipoprotein on vascular cells. Atherosclerosis 2006;185:219-226.

$>5$ Ishigaki Y, Oka Y, Katagiri H: Circulating oxidized LDL: a biomarker and a pathogenic factor. Curr Opin Lipidol 2009;20:363-369.

-6 Heery JM, Kozak M, Stafforini DM, Jones DA, Zimmerman GA, McIntyre TM, Prescott SM: Oxidatively modified LDL contains phospholipids with platelet-activating factor-like activity and stimulates the growth of smooth muscle cells. J Clin Invest 1995;96:23222330 .

7 Marathe GK, Zimmerman GA, Prescott SM, McIntyre TM: Activation of vascular cells by PAF-like lipids in oxidized LDL. Vascul Pharmacol 2002;38:193-200

-8 Stafforini DM, McIntyre TM, Zimmerman GA, Prescott SM: Plateletactivating factor, a pleiotrophic mediator of physiological and pathological processes. Crit Rev Clin Lab Sci 2003;40:643-672.

$\checkmark 9$ Montrucchio G, Alloatti G, Camussi G: Role of platelet-activating factor in cardiovascular pathophysiology. Physiol Rev 2000;80:1669-1699.

$\checkmark 10$ Bussolati B, Biancone L, Cassoni P, Russo S, Rola-Pleszczynski M, Montrucchio G, Camussi G: PAF produced by human breast cancer cells promotes migration and proliferation of tumor cells and neoangiogenesis. Am J Pathol 2000;157:1713-1725.

$\checkmark 11$ Axelrad TW, Deo DD, Ottino P, Van Kirk J, Bazan NG, Bazan HE, Hunt JD: Platelet-activating factor (PAF) induces activation of matrix metalloproteinase 2 activity and vascular endothelial cell invasion and migration. FASEB J 2004;18:568-570.

$>12$ Stengel D, O’Neil C, Brocheriou I, Karabina SA, Durand H, Caplice NM, Pickering JG, Ninio E: PAF-receptor is preferentially expressed in a distinct synthetic phenotype of smooth muscle cells cloned from human internal thoracic artery: functional implications in cell migration. Biochem Biophys Res Commun 2006;346:693-699.
Honda Z, Ishii S, Shimizu T: Platelet- $>25$ activating factor receptor. J Biochem 2002;131:773-779.

Chamberlain G, Fox J, Ashton B, Middleton J: Concise review: mesenchymal stem cells: their phenotype, differentiation capacity, immunological features, and potential for homing. Stem Cells 2007;25:2739-2749. Phinney DG, Prockop DJ: Concise review: mesenchymal stem/multipotent stromal cells: the state of transdifferentiation and modes of tissue repair-current views. Stem Cells 2007;25:2896-2902.

Caplan AI, Dennis JE: Mesenchymal stem cells as trophic mediators. J Cell Biochem 2006;98:1076-1084.

Jeon ES, Park WS, Lee MJ, Kim YM, Han J, Kim JH: A Rho kinase/myocardinrelated transcription factor-A-dependent mechanism underlies the sphingosylphosphorylcholine-induced differentiation of mesenchymal stem cells into contractile smooth muscle cells. Circ Res 2008;103:635-642.

Kinner B, Zaleskas JM, Spector M: Regulation of smooth muscle actin expression and contraction in adult human mesenchymal stem cells. Exp Cell Res 2002;278:72-83.

Wang D, Park JS, Chu JS, Krakowski A, Luo K, Chen DJ, Li S: Proteomic profiling of bone marrow mesenchymal stem cells upon transforming growth factor betal stimulation. J Biol Chem 2004;279:43725-43734.

Farrington-Rock C, Crofts NJ, Doherty MJ, Ashton BA, Griffin-Jones C, Canfield AE: Chondrogenic and adipogenic potential of microvascular pericytes. Circulation 2004;110:2226-2232.

Hirschi KK, Goodell MA: Hematopoietic, vascular and cardiac fates of bone marrow-derived stem cells. Gene Ther 2002;9:648-652.

Qian H, Yang Y, Li J, Huang J, Dou K, Yang G: The role of vascular stem cells in atherogenesis and post-angioplasty restenosis. Ageing Res Rev 2007;6:109127.

23 Lee MJ, Song HY, Kim MR, Sung SM, Jung JS, Kim JH: Oncostatin M stimulates expression of stromal-derived factor-1 in human mesenchymal stem cells. Int J Biochem Cell Biol 2007;39:650-659.

Steinbrecher UP, Parthasarathy S, Leake DS, Witztum JL, Steinberg D: Modification of low density lipoprotein by endothelial cells involves lipid peroxidation and degradation of low density lipoprotein phospholipids. Proc Natl Acad Sci U S A 1984;81:3883-3887.
Law RE, Meehan WP, Xi XP, Graf K, Wuthrich DA, Coats W, Faxon D, Hsueh WA: Troglitazone inhibits vascular smooth muscle cell growth and intimal hyperplasia. J Clin Invest 1996;98:18971905.

26 Huang S, Jiang Y, Li Z, Nishida E, Mathias P, Lin S, Ulevitch RJ, Nemerow GR, Han $\mathrm{J}$ : Apoptosis signaling pathway in T cells is composed of ICE/Ced-3 family proteases and MAP kinase kinase $6 \mathrm{~b}$. Immunity 1997;6:739-749.

27 Marathe GK, Prescott SM, Zimmerman GA, McIntyre TM: Oxidized LDL contains inflammatory PAF-like phospholipids. Trends Cardiovasc Med 2001;11:139-142.

28 Beaudeux JL, Said T, Ninio E, Ganne F, Soria J, Delattre J, Soria C, Legrand A, Peynet J: Activation of PAF receptor by oxidised LDL in human monocytes stimulates chemokine releases but not urokinase-type plasminogen activator expression. Clin Chim Acta 2004;344:163-171.

29 Watson AD, Leitinger N, Navab M, Faull KF, Horkko S, Witztum JL, Palinski W, Schwenke D, Salomon RG, Sha W, Subbanagounder G, Fogelman AM, Berliner JA: Structural identification by mass spectrometry of oxidized phospholipids in minimally oxidized low density lipoprotein that induce monocyte/endothelial interactions and evidence for their presence in vivo. J Biol Chem 1997;272:13597-13607.

Pegorier S, Stengel D, Durand H, Croset M, Ninio E: Oxidized phospholipid: POVPC binds to platelet-activatingfactor receptor on human macrophages. Implications in atherosclerosis. Atherosclerosis 2006;188:433-443.

Coffer PJ, Geijsen N, M'rabet L, Schweizer RC, Maikoe T, Raaijmakers JA, Lammers JW, Koenderman L: Comparison of the roles of mitogenactivated protein kinase kinase and phosphatidylinositol 3-kinase signal transduction in neutrophil effector function. Biochem J 1998;329:121-130. DeCoster MA, Mukherjee PK, Davis RJ, Bazan NG: Platelet-activating factor is a downstream messenger of kainateinduced activation of mitogen-activated protein kinases in primary hippocampal neurons. J Neurosci Res 1998;53:297303.

$\$ 3$ Maruoka S, Hashimoto S, Gon Y, Takeshita I, Horie T: PAF-induced RANTES production by human airway smooth muscle cells requires both p38 MAP kinase and Erk. Am J Respir Crit Care Med 2000;161:922-929. 
34 Huang C, Jacobson K, Schaller MD: MAP kinases and cell migration. J Cell Sci 2004;117:4619-4628.

$>35$ Klemke RL, Cai S, Giannini AL, Gallagher PJ, de Lanerolle P, Cheresh DA: Regulation of cell motility by mitogenactivated protein kinase. J Cell Biol 1997;137:481-492.

36 Hedges JC, Dechert MA, Yamboliev IA, Martin JL, Hickey E, Weber LA, Gerthoffer WT: A role for p38(MAPK)/ HSP27 pathway in smooth muscle cell migration. J Biol Chem 1999;274:2421124219.

$\$ 3$ Matsumoto T, Yokote K, Tamura K, Takemoto M, Ueno H, Saito Y, Mori S: Platelet-derived growth factor activates p38 mitogen-activated protein kinase through a Ras-dependent pathway that is important for actin reorganization and cell migration. J Biol Chem 1999;274:13954-13960.

-38 Spaeth E, Klopp A, Dembinski J, Andreeff M, Marini F: Inflammation and tumor microenvironments: defining the migratory itinerary of mesenchymal stem cells. Gene Ther 2008;15:730-738.
39 Dwyer RM, Potter-Beirne SM, Harrington KA, Lowery AJ, Hennessy E, Murphy JM, Barry FP, O’Brien T, Kerin MJ: Monocyte chemotactic protein-1 secreted by primary breast tumors stimulates migration of mesenchymal stem cells. Clin Cancer Res 2007; 13:5020-5027.

Ji JF, He BP, Dheen ST, Tay SS: Interactions of chemokines and chemokine receptors mediate the migration of mesenchymal stem cells to the impaired site in the brain after hypoglossal nerve injury. Stem Cells 2004;22:415-427.

41 Kang YJ, Jeon ES, Song HY, Woo JS, Jung JS, Kim YK, Kim JH: Role of c-Jun $\mathrm{N}$-terminal kinase in the PDGF-induced proliferation and migration of human adipose tissue-derived mesenchymal stem cells. J Cell Biochem 2005;95:1135-45.

42 Lee MJ, Jeon ES, Lee JS, Cho M, Suh DS, Chang CL, Kim JH: Lysophosphatidic acid in malignant ascites stimulates migration of human mesenchymal stem cells. J Cell Biochem 2008;104:499-510. Li C, Kong Y, Wang H, Wang S, Yu H, Liu X, Yang L, Jiang X, Li L, Li L: Homing of bone marrow mesenchymal stem cells mediated by sphingosine 1phosphate contributes to liver fibrosis. J Hepatol 2009;50:1174-1183.
Meriane M, Duhamel S, Lejeune L, Galipeau J, Annabi B: Cooperation of matrix metalloproteinases with the RhoA/Rho kinase and mitogen-activated protein kinase kinase-1/extracellular signal-regulated kinase signaling pathways is required for the sphingosine1-phosphate-induced mobilization of marrow-derived stromal cells. Stem Cells 2006;24:2557-2565.

45 Li M, Yu J, Li Y, Li D, Yan D, Qu Z, Ruan Q: CXCR4 positive bone mesenchymal stem cells migrate to human endothelial cell stimulated by ox-LDL via SDF1alpha/CXCR4 signaling axis. Exp Mol Pathol 2010;88:250-255.

Yu J, Li Y, Li M, Qu Z, Ruan Q: Oxidized low density lipoprotein-induced transdifferentiation of bone marrowderived smooth muscle-like cells into foam-like cells in vitro. Int J Exp Pathol 2010;91:24-33.

$\checkmark 47$ Parhami F, Jackson SM, Tintut Y, Le V, Balucan JP, Territo M, Demer LL: Atherogenic diet and minimally oxidized low density lipoprotein inhibit osteogenic and promote adipogenic differentiation of marrow stromal cells. J Bone Miner Res 1999;14:2067-2078. 